\title{
FAKTOR-FAKTOR YANG MEMENGARUHI DUPLIKASI PENOMORAN REKAM MEDIS DI RUMAH SAKIT UMUM MADANI MEDAN
}

\author{
1. Suheri Parulian Gultom; ${ }^{2}$ Erna Wati Pakpahan \\ 1. Dosen Prodi D-III Perekam Dan Infokes Imelda, Jalan Bilal Nomor 52 Medan; 2.Alumni D-III Perekam \\ Dan Infokes Imelda
}

\author{
E-mail: ${ }^{1 .}$ suheriparuliangultom@gmail.com \\ 2. Ernawatipakpahan@gmail.com
}

\begin{abstract}
ABSTRAK
Sistem penomoran yang digunakan di RSU Madani yaitu unit numbering system dimana pasien yang berkunjung ke rumah sakit tersebut hanya memiliki satu nomor rekam medis yang digunakan untuk selamanya berobat. Tempat penerimaan pasien tidak memiliki Standard Operating Procedure (SOP) tentang sistem penomoran, sehingga masih di temukan adanya duplikasi nomor rekam medis, satu nomor rekam medis diindikasikan dimiliki oleh beberapa pasien. Diketahui juga bahwa sering terjadi penomoran ganda akibat kurang telitinya petugas rekam medis pada saat mencari dan menyimpan rekam medis pasien lama yang sudah pernah berobat, penomoran manual pada saat melakukan pendaftaran, komputerisasi yang terbatas, minimnya petugas rekam medis di bagian pendaftaran. Hal yang bisa saja terjadi seperti kesalahan dalam melakukan tindakan dikarenakan diagnosa terakhir atau tindakan terakhir yang tertera di berkas rekam medis ganda tersebut, bukan terakhir di pergunakan pada saat pasien mendapatkan pelayanan medis. Penelitian ini menggunakan penelitian deskriptif kuantitatif melalui wawancara, observasi dan studi dokumentasi. Populasi dan sampel penelitian adalah petugas rekam medis di pendaftaran sebanyak 8 orang. Hasil penelitian menunjukkan bahwa latar belakang pendidikan petugas rekam medis sebagian besar D-III kesehatan sebanyak 5 responden (41,6\%), sebagian kecil berpendidikan D-III rekam medis sebanyak 1 (8,3\%). Sistem penomoran menggunakan straight numbering system atau sistem penomoran secara langsung namun dalam melaksanakan pengelolaan penomorannya belum terlaksanakan dengan baik karena pada RSU Madani belum adanya penetapan tentang standar operasional prosedur di unit rekam medis untuk penomoran. Tidak tersedianya Kartu Indeks Utama Pasien (KIUP). Hal ini dikarenakana standar operasional prosedur dalam pengembangan sarana dan prasarana belum ada dan kurangnya pengetahuan petugas rekam medis tentang KIUP. Diharapkan pada pimpinan RSU Madani agar melakukan pelatihan kepada petugas rekam medis khususnya dibagian pendaftaran dan penyimpanan agar kinerjanya semakin baik.
\end{abstract}

Kata kunci : Rekam Medis, Duplikasi Penomoran

\section{PENDAHULUAN}

Rumah sakit merupakan instansi yang mempunyai peran penting dalam meningkatkan upaya kesehatan per orangan atau individu. Dalam pelayanan kesehatan, rumah sakit selalu berusaha untuk memberikan pelayanan yang terbaik bagi pasien. Diantaranya dengan mencatat semua tindakan pelayanan kesehatan yang diberikan terhadap pasien dan semua data sosial serta riwayat kesehatan pasien. Data pasien tersebut dicatat dalam sebuah berkas atau dokumen yang disebut dengan rekam medis. Dimana salah satu pelaksanaannya adalah bagaimana cara pemberian nomor rekam medis.

Menurut Undang-undang RI No. 44 Tahun 2009, rumah sakit adalah institusi pelayanan kesehatan yang menyelenggarakan pelayanan kesehatan per orangan secara paripurna yang menyediakan pelayanan rawat inap, rawat jalan dan gawat darurat. Salah satu 
pelayanan kesehatan di rumah sakit yang sangat dibutuhkan dan merupakan pintu masuk pelayanan kesehatan adalah rekam medis.

Rekam medis adalah berkas yang berisikan catatan dan dokumen tentang identitas pasien, pemeriksaan, pengobatan, tindakan dan pelayanan lain yang telah diberikan kepada pasien (Permenkes RI, 2008). Rekam medis yang baik adalah apabila memiliki data yang continue sejak awal hingga akhir perawatan di berikan atau sejak pasien mendaftar pertama kali hingga pasien menjadi pasien in aktif. Kesinambungan data rekam medis merupakan satu hal yang mutlak dipenuhi dalam menjaga nilai rekam medis yang baik untuk mendukung kesehatan yang maksimal (Huffman, 1999).

Rekam medis bertujuan untuk menunjang tercapainya tertib administrasi dalam rangka upaya peningkatan pelayanan kesehatan di rumah sakit, dimana tanpa adanya dukungan suatu sistem pengelolaan rekam medis yang baik dan benar, maka tertib administrasi di rumah sakit tidak akan berhasil sebagaimana yang diharapkan. Sedangkan tertib administrasi merupakan salah satu faktor yang menentukan upaya pelayanan kesehatan di suatu rumah sakit (Depkes RI, 2006).

Penyelenggaraan rekam medis merupakan proses kegiatan yang dimulai pada saat diterimanya pasien di rumah sakit, kegiatan pencatatan data medis pasien selama mendapatkan pelayanan kesehatan dan dilanjutkan dengan penanganan berkas rekam medis yang meliputi penyimpanan dan pengeluaran berkas dari tempat penyimpanan untuk melayani permintaan atau peminjaman serta retensi setiap formulir rekam medis sesuai ketentuan yag sudah ada (Depkes RI, 2008).

Berkas rekam medis pasien pertama sekali berkunjung di rumah sakit akan disimpan sesuai dengan peraturan yang ada. Berkas rekam medis berisi data individual yang bersifat rahasia, maka setiap lembar formulir berkas rekam medis berisi data dan informasi hasil pelayanan yang diperoleh pasien secara individu. Jika pasien berobat ulang, maka berkas rekam medis di ambil kembali dari rak penyimpanan. Berkas rekam medis akan di retensi minimal 5 (lima) tahun terhitung tanggal terakhir sejak pasien berobat di rumah sakit.

Dalam meningkatkan mutu pelayanan rumah sakit dan pengembangannya diperlukan pengelolaan setiap unit rumah sakit yang efektif dan efisien. Keberhasilan pelayanan kesehatan dimulai pada bagian pendaftaran, dimana pasien yang datang ke rumah sakit seharusnya mendapatkan satu nomor rekam medis baik rawat jalan maupun rawat inap. Penomoran rekam medis di rumah sakit pada umumnya menggunakan unit numbering sistem karena memiliki kelebihan dan keefisienan. Penomoran berperan penting dalam memudahkan pencarian rekam medis pada waktu pasien datang kembali untuk berobat sehingga data pasien tetap terdokumentasi dengan baik.

RSU Madani diresmikan pada tahun 2014 yang berlokasi di Jl. AR. Hakim No. 168 Medan dan merupakan salah satu rumah sakit umum swasta tipe C di kota Medan yang mendapat Akreditasi Pratama dari Komite Akreditasi Rumah Sakit (KARS) pada bulan November tahun 2016.

Menurut survey pendahuluan yang dilakukan pada bulan Maret 2019 di RSU Madani, dari penomoran 30 rekam medis, terdapat duplikasi penomoran sebanyak 13,3 $\%$ dan tidak terjadi duplikasi sebanyak $86,7 \%$. Sistem penomoran merupakan kunci utama dalam penyelenggaraan rekam medis. Terjadinya duplikasi nomor rekam medis pasien dapat menyebabkan pelayanan kesehatan terganggu dan riwayat penyakit pasien tidak terdokumentasikan dengan baik.

Berdasarkan wawancara dengan petugas rekam medis di bagian pendaftaran diketahui sistem penomoran yang digunakan di RSU Madani yaitu unit numbering system dimana pasien yang berkunjung ke rumah sakit tersebut hanya memiliki satu nomor rekam medis yang digunakan untuk selamanya berobat. Tempat Penerimaan pasien tidak memiliki Standard Operating Procedure (SOP) tentang sistem penomoran, sehingga masih di temukan adanya duplikasi nomor rekam medis, satu 
nomor rekam medis diindikasikan dimiliki oleh beberapa pasien.

Diketahui juga bahwa sering terjadi penomoran ganda akibat kurang telitinya petugas rekam medis pada saat mencari dan menyimpan rekam medis pasien lama yang sudah pernah berobat, penomoran manual pada saat melakukan pendaftaran, komputerisasi yang terbatas, minimnya petugas rekam medis di bagian pendaftaran. Hal yang bisa saja terjadi seperti kesalahan dalam melakukan tindakan dikarenakan diagnosa terakhir atau tindakan terakhir yang tertera di berkas rekam medis ganda tersebut, bukan terakhir di pergunakan pada saat pasien mendapatkan pelayanan medis.

Penelitian yang dilakukan oleh Irmawati (2014), Joint Commision on Acreditation of Health Organization $(\mathrm{JCAHO})$ menganjurkan untuk menggunakan sistem penomoran unit (Unit Numbering System) dalam memberikan nomor rekam medis pada setiap pasien. Akan tetapi masih terdapat kejadian mengenai duplikasi nomor rekam medis pada berkas rekam medis. Duplikasi yang terjadi bukan hanya satu pasien dengan lebih dari satu nomor rekam medis tetapi ada juga duplikasi yang berupa satu nomor rekam medis yang digunakan untuk lebih dari satu pasien. Hal tersebut akan mempengaruhi sistem pengambilan kembali berkas rekam medis dan dapat juga mengakibatkan kesalahan dalam melakukan tindakan medis karena diagnosa terakhir atau pengobatan terakhir yang tercatat, bukan merupakan catatan terakhir yang dipergunakan pada saat pasien mendapatkan pelayanan medis.

Sesuai penelitian yang dilakukan oleh Muldiana dan Widjaja (2016), tentang faktor-faktor yang memengaruhi terjadi duplikasi penomoran di Rumah Sakit Atma Jaya, diketahui bahwa duplikasi penomoran rekam medis pada saat pendaftaran pasien terjadi setiap harinya sekitar 1-4 orang pasien. Faktornya adalah kualifikasi pendidikan, pengetahuan dan pengalaman kurang teliti dan kurang mengetahui tentang sistem penomoran rekam medis.

Penelitian selanjutnya dilakukan oleh Silaban (2015) di RSU Imelda Pekerja Indonesia Medan, menunjukkan bahwa dari
710 berkas rekam medis terdapat duplikasi penomoran sebanyak $1,45 \%$ dan tidak terduplikasi $98,55 \%$. Penelitian oleh Ochtavira (2016) di RSU Bhayangkara Tebing Tinggi, didapatkan bahwa dari 240 berkas rekam medis pada kunjungan bulan Januari sampai dengan Mei diperoleh nomor rekam medis yang terjadi duplikasi sebanyak $16,7 \%$ ) dan yang tidak terduplikasi $83,3 \%$.

\section{Perumusan Masalah}

Bagaimana sistem penomoran dan faktor-faktor yang memengaruhi duplikasi penomoran rekam medis di RSU Madani?

\section{Tujuan Penelitian}

Penelitian ini bertujuan untuk mengetahui sistem penomoran dan faktorfaktor yang memengaruhi duplikasi penomoran rekam medis di RSU Madani.

\section{Manfaat Penelitian}

1. Menghasilkan informasi tentang sistem penomoran rekam medis di RSU Madani dan masukan kepada pimpinan serta manajemen dalam menyusun standar prosedur operasional terkait upaya mencegah duplikasi penomoran rekam medis.

2. Menjadi bahan referensi dalam peningkatan Ilmu Rekam Medis dan Informasi Kesehatan (RMIK) khususnya dalam pemberian nomor rekam medis di rumah sakit.

3. Menjadi bahan informasi, edukasi dan perbandingan bagi peneliti selanjutnya yang berhubungan dengan masalah penelitian ini.

\section{METODE}

\section{Jenis Penelitian}

Jenis yang digunakan dalam penelitian ini adalah deskriptif kuantitatif dengan rancangan cross sectional yaitu untuk mengetahui faktor-faktor yang memengaruhi duplikasi penomoran rekam medis di RSU Madani Medan Tahun 2019.

\section{Lokasi dan Waktu Penelitian}

Penelitan dilakukan di RSU Madani Medan. Adapun alasan pemilihan lokasi 
penelitian, karena ditemukan masalah duplikasi penomoran rekam medis baik penomoran ganda maupun terdapatnya nomor rekam medis pasien lebih dari satu nomor. Penelitian ini dilakukan pada bulan Februari sampai dengan Mei 2019. Diawali dengan pengajuan judul, penyusunan proposal, hasil penelitian dan seminar hasil.

\section{Populasi}

Populasi dari penelitian ini adalah petugas rekam medis di bagian pendaftaran dan kepala rekam medis di RSU Madani Medan berjumlah 8 orang .

\section{Sampel dan Teknik Sampling}

Sampel dalam penelitian ini adalah petugas rekam medis di bagian pendaftaran di RSU Madani Medan sebanyak 8 orang. Teknik sampling yang digunakan adalah total sampling yaitu seluruh petugas rekam medis di bagian pendaftaran di RSU Madani Medan dijadikan sampel.

\section{Jenis dan Metode Pengumpulan Data}

Adapun sumber data yang digunakan yaitu:

1. Data primer

Data primer diperoleh langsung dari petugas rekam medis melalui wawancara dan dari hasil observasi.

2. Data sekunder

Data sekunder adalah data dokumentasi atau data laporan yang sudah tersedia di RSU Madani.

\section{Instrumen Penelitian}

Instrumen penelitian yang digunakan dalam penelitian ini yaitu pedoman wawancara dan dan lembar checklist untuk observasi.

\section{Teknik Analisa Data}

Dalam penelitian ini analisa data dilakukan secara deskriptif melalui reduksi data, penyajian dan penarikan kesimpulan, sehingga diperoleh gambaran yang jelas tentang faktor yang memengaruhi duplikasi penomoran rekam medis di Rumah Sakit Umum Madani Medan.
HASIL

\section{Gambaran Umum Lokasi Penelitian}

Rumah Sakit Umum Madani Medan beralamat di Jalan A. R. Hakim No. 168 Kelurahan Suka Ramai I Kecamatan Medan Area Kota Medan dibangun di atas lahan seluas $\mathbf{1 . 1 1 6} \mathbf{~ m}^{2}$ dan luas bangunan sebesar 3.209,52 $\mathrm{m}^{2}$ yang terdiri dari 4 (empat) lantai. Rumah sakit ini pada awalnya adalah Klinik Madani yang didirikan pada Agustus 2008 ditandai dengan keluarnya Surat Izin Sarana Pelayanan Kesehatan Dasar Swasta oleh Dinas Kesehatan Kota Medan Nomor : 445/1227/VII/08 Tanggal 26 Agustus 2008. Sejalan dengan kebutuhan kesehatan dan meningkatnya kepercayaan masyarakat, maka pemilik Klinik Madani berencana untuk meningkatkan status klinik menjadi Rumah Sakit Umum Madani.

\section{Gambaran Duplikasi Penomoran Rekam Medis}

Sistem penomoran yang diterapkan di RSU Madani menggunakan unit numbering system (sistem penomoran unit), sistem ini merupakan pemberian nomor yang paling baik untuk efisiensi tempat penyimpanan dokumen rekam medis di RSU Madani.

Berdasarkan observasi yang dilakukan di RSU Madani selama 1 bulan, peneliti menemukan beberapa masalah, satu diantaranya adalah sering terjadi duplikasi penomoran pada saat pendaftaran pasien dimana didapatkan pasien yang mendapatkan nomor ganda pada setiap harinya sekitar 1-2 orang pasien. yang Dari catatan rekam medis ganda tersebut dapat dijumlah berapa pasien yang mendapatkan nomor ganda. Sistem registrasi tempat pendaftaran pasien hanya dapat melakukan entry data yang fungsinya sebagai indeks master pasien. Sistem komputerisasi sangat sederhana dan belum dapat diurut indeks pasiennya berdasarkan nama atau tanggal lahir yang dapat digunakan untuk mencari pasien yang nomor rekam medis ganda. Selain itu ada 3 (tiga) tempat pendaftaran yang sudah terkomputerisasi tetapi saling berhubungan satu sama lain, maka semakin besar pengaruh terjadinya duplikasi penomoran rekam medis di RSU Madani. 
Berdasarkan hasil wawancara dengan petugas pendaftaran dan kepala unit rekam medis, menemukan beberapa akibat bila terjadi duplikasi penomoran rekam medis yaitu :

a. Pelayanan terhambat karena lamanya dalam pencarian berkas rekam medis dikarenakan tracer tidak ada.

b. Isi rekam medis kurang berkesinambungan.

c. Rak dan ruang penyimpanan berkas rekam medis jumlahnya terbatas sehingga penyusunan tidak rapi mengakibatkan terjadinya duplikasi penomoran rekam medis.

d. Pasien yang telah mendapatkan nomor rekam medis baru lagi, bila tidak diketahui sebagai nomor ganda maka rekam medis yang pertama akan ikut sebagai rekam medis inaktif saat retensi.

e. Biaya menjadi meningkat karena penggunaan map yang lebih banyak.

f. Khusus pasien asuransi perlu diminta foto copy KTP agar tidak terjadi penyalahgunaan pemakaian kartu asuransi.

Berdasarkan wawancara yang dilakukan terhadap petugas pendaftaran, didapatkan bahwa responden kurang memahami tentang pentingnya pemberian nomor rekam medis terhadap pasien, kurang mengetahui alur penerimaan pasien dan atau alur pendaftaran. Selanjutnya diketahui juga bahwa petugas kurang teliti dalam mengidentifikasi pasien.

\section{Karakteristik Responden}

Berdasarkan hasil penelitian menunjukkan bahwa sebagian besar responden berumur $>22$ tahun sebanyak 6 orang $(75,0 \%)$, sebagian kecil berumur $<22$ tahun sebanyak 2 orang $(25,0 \%)$. Berdasarkan jenis kelamin, sebagian besar responden berjenis kelamin perempuan sebanyak 7 orang $(87,5 \%)$, sebagian kecil berjenis kelamin laki-laki sebanyak 1 orang $(12,5 \%)$. Berdasarkan status perkawinan, seluruh responden belum kawin sebanyak 8 orang $(100,0 \%)$

Hasil penelitian ini sebagian besar responden bekerja $<5$ tahun sebanyak 7 orang $(87,5 \%)$, sedangkan yang bekerja $>5$ tahun sebanyak 1 orang (12,5\%). Berdasarkan pendidikan, seluruh responden berpendidikan SLTA/ Sederajat sebanyak 8 orang $(100,0 \%)$. Berdasarkan pelatihan rekam medis, sebagian besar responden tidak mengikuti pelatihan rekam medis sebanyak 6 orang $(75,0 \%)$, sebagian kecil responden pernah mengikuti pelatihan rekam medis sebanyak 2 orang $(25,0 \%)$. Berdasarkan hasil penelitian, karakteristik responden dapat dilihat pada Tabel 4.1 berikut ini.

Tabel 1. Distribusi Frekuensi Berdasarkan Karakteristik Responden di Rumah Sakit Umum Madani Tahun 2019.

\begin{tabular}{|c|c|c|c|}
\hline No & Karakteristik & $\begin{array}{c}\text { Jumlah } \\
\text { (n) }\end{array}$ & $(\%)$ \\
\hline \multicolumn{4}{|c|}{ Umur } \\
\hline \multirow[t]{2}{*}{1} & $<22$ tahun & 2 & 25,0 \\
\hline & $>22$ tahun & 6 & 75,0 \\
\hline \multirow[t]{3}{*}{2} & Jenis Kelamin & & \\
\hline & Laki-laki & 1 & 12,5 \\
\hline & Perempuan & 7 & 87,5 \\
\hline \multirow[t]{4}{*}{3} & Status Perkawinan & & \\
\hline & Belum & 8 & \\
\hline & Kawin & & 100,0 \\
\hline & Kawin & 0 & 0,0 \\
\hline \multirow[t]{3}{*}{4} & Pendidikan & & \\
\hline & $\begin{array}{l}\text { SLTA/Sed } \\
\text { erajat }\end{array}$ & 8 & 100,0 \\
\hline & Lain-lain & 0 & 0,0 \\
\hline \multirow[t]{3}{*}{5} & Masa Kerja & & \\
\hline & $<5$ tahun & 7 & 87,5 \\
\hline & $>5$ tahun & 1 & 12,5 \\
\hline \multirow[t]{4}{*}{6} & Pelatihan & & \\
\hline & Pernah & 2 & 25,0 \\
\hline & $\begin{array}{l}\text { Tidak } \\
\text { pernah }\end{array}$ & 6 & 75,0 \\
\hline & Total & 8 & 100,0 \\
\hline
\end{tabular}

Berdasarkan jumlah sampel 233 berkas rekam medis di ruangan penyimpanan, didapatkan bahwa terjadi duplikasi nomor rekam medis sebanyak 32 rekam medis $(13,73 \%)$ dan yang tidak mengalami duplikasi nomor berkas rekam medis sebanyak 201 rekam medis $(86,26 \%)$. Secara rinci dapat dilihat pada Tabel 4.2 dibawah ini : 
Tabel 2. Gambaran Kejadian Duplikasi Penomoran Berkas Rekam Medis di Rumah Sakit Umum Madani Tahun 2019.

\begin{tabular}{lcc}
\hline $\begin{array}{c}\text { Berkas Rekam } \\
\text { Medis }\end{array}$ & Jumlah (n) & $\begin{array}{c}\text { Persentase } \\
(\%)\end{array}$ \\
\hline Duplikasi & 32 & $13.73 \%$ \\
\hline Tidak Duplikasi & 201 & $86.26 \%$ \\
\hline
\end{tabular}

\section{Ketersediaan Prosedur Tetap di Instalasi Rekam Medis RSU Madani}

Sistem penyimpanan di RSU Madani, yaitu sentralisasi dimana semua berkas rekam medis baik rawat jalan, rawat inap dan gawat darurat disimpan dalam satu berkas dan satu tempat. Selanjutnya, sistem penjajaran berkas rekam medis, yaitu : terminal digit filling system, dimana dengan menjajarkan berkas rekam medis berdasarkan urutan nomor rekam medis pada dua angka kelompok akhir.

Berdasarkan dari hasil hasil observasi peneliti, ada beberapa berkas yang tidak berurut, duplikasi dan missfile. Terjadinya hal tersebut mengakibatkan terdapat kekeliruan dan lamanya dalam pencarian berkas rekam medis yang dibutuhkan.

Kemudian sistem penomoran yang digunakan di RSU Madani, yaitu : sistem penomoran dengan cara unit (unit numbering system), dimana pada sistem ini memberikan satu nomor rekam medis kepada pasien rawat jalan, rawat inap dan gawat darurat. Nomor rekam medis tersebut dapat digunakan selamanya untuk kunjungan berikutnya. Selain itu, tidak terdapatnya standar operasional prosedur (SOP) untuk penomoran dan penyimpanan berkas rekam medis. Hal ini mengakibatkan tidak adanya keseragaman dalam memberikan nomor terhadap rekam medis sehingga dapat mengakibatkam duplikasi penomoran berkas rekam medis.

\section{Ketersediaan Sarana dan Prasarana di Instalassi Rekam Medis RSU Madani}

Hasil observasi di RSU Madani, tidak terdapatnya Kartu Indeks Utama Pasien (KIUP). Hal ini dikarenakana standar operasional prosedur dalam pengembangan sarana dan prasarana belum ada dan kurangnya pengetahuan petugas rekam medis tentang KIUP. Dengan tidak adanya
KIUP ini, maka petugas akan kesulitan dalam melayani pasien yang tidak membawa kartu berobat dan petugas memberi nomor baru kepada pasien, maka dari itu terjadinya duplikasi berkas rekam medis.

Selanjutnya tidak terdapat kartu tracer atau petunjuk keluar berkas rekam medis dimana hanya menggunakan kertas yang ditempel pada map rekam medis dengan ditulis spidol dan juga komputer yang masih terbatas jumlahnya. Hasil observasi, ditemukan tidak adanya buku register pasien di instalasi rawat jalan, hanya menggunakan buku tulis biasa.

Ruangan penyimpanan rekam medis di RSU Madani terdiri dari dua tempat di lantai satu dan dua karena luas ruangan yang terbatas. Suhu ruangan penyimpanan normal, terdapat rak penyimpanan terbuka dan petunjuk rak sehingga memudahkan petugas dalam pengambilan berkas rekam medis. Jarak antara rak penyimpanan berjarak $52 \mathrm{~cm}$ dan ini tidak sesuai dengan standar dimana harus berjarak $90 \mathrm{~cm}$.

\section{PEMBAHASAN}

\section{Gambaran Duplikasi Penomoran Rekam Medis}

Sistem penomoran yang digunakan di RSU Madani adalah unit numbering system (sistem penomoran unit) dimana satu pasien hanya diberikan satu nomor rekam medis baik untuk rawat jalan maupun rawat inap.

Untuk menghindari terjadinya duplikasi penomoran, seharusnya petugas rekam medis dibagian pendaftaran pasien baik rawat jalan maupun rawat inap menanyakan apakah pasien tersebut pernah berobat atau tidak sehingga tidak terjadi duplikasi penomoran rekam medis dan petugas harus lebih teliti dalam melayani pasien agar tidak terdapat lagi pasien lama berkunjung sebagai pasien baru, kemudian diberikan nomor rekam medis baru yang menyebabkan duplikasi penomoran rekam medis.

Sistem registrasi hanya dapat melakukan entry data yang berfungsi sebagai indeks master pasien. Belum mempunyai sistem pelaporan dikarenakan sistem komputerisasi yang sederhana, tidak dapat membuat indeks pasien yang dapat 
digunakan sebagai data pasien dengan duplikasi penomoran rekam medis. Seharusnya duplikasi penomoran rekam medis tidak terjadi, sebab menurut Permenkes 269 Tahun 2008, rekam medis merupakan berkas yang berisikan catatan dan dokumen tentang identitas pasien, pemeriksaan, pengobatan, tindakan dan pelayanan lain yang telah diberikan kepada pasien, sehingga saat terjadinya duplikasi penomoran maka pengobatan pasien menjadi tidak berkesinambungan. Menurut Budhi (2011), menyatakan bahwa petugas penerimaan pasien harus menguasai alur pelayanan pasien, alur berkas rekam medis dan prosedur penerimaan pasien sehingga petugas dapat memberikan pelayanan dan informasi yang tepat dan cepat. Prosedur sebaiknya diletakan di tempat yang mudah dibaca oleh petugas pendaftaran pasien, hal ini bertujuan untuk mengontrol pekerjaan yang telah dilakukan sehingga pekerjaan yang dilakukan dapat konsisten dan sesuai aturan. Akan tetapi kenyataan dilapangan hingga saat ini sosialisasi mengenai Standar Operasional Prosedur (SOP) tentang pendaftaran pasien belum berjalan dengan baik, hal ini dibuktikan dengan terdapatnya petugas yang tidak mengetahui langkah apa saja yang harus dilakukan saat melakukan pekerjaan.

\section{Gambaran Pendidikan Petugas Rekam Medis Terhadap Duplikasi Penomoran}

Dari hasil studi dokumentasi di RSU Madani, jumlah petugas rekam medis secara keseluruhan sebanyak 30 orang. Sedangkan yang bekerja di unit pendaftaran pasien sebanyak 8 orang, dimana seluruhnya berpendidikan SLTA/ Sederajat. Tidak adanya petugas yang berpendidikan rekam medis di unit pendaftaran pasien, maka dapat menjadi faktor penyebab terjadinya duplikasi penomoran rekam medis, hal ini dikarenakan petugas kurang mengetahui tentang sistem penomoran rekam medis.

Pendidikan adalah suatu usaha mengembangkan kepribadian dan kemampuan didalam dan diluar sekolah dan berlangsung seumur hidup. Pendidikan memengaruhi proses belajar, makin tinggi pendidikan seseorang makin mudah orang tersebut untuk menerima informasi. Dengan pendidikan tinggi maka seseorang akan cenderung untuk mendapatkan informasi yang masuk dan semakin banyak pengetahuan yang didapat tentang kesehatan. Pengetahuan sangat erat kaitannya dengan pendidikan tinggi, maka orang tersebut akan semakin luas pengetahuannya. Akan tetapi perlu ditekankan bahwa seorang yang berpendidikan rendah tidak berarti mutlak pengetahuan rendah. Peningkatan pengetahuan tidak mutlak diperoleh dari pendidikan formal, akan tetapi juga dapat diperoleh pada pendidikan non formal. Pengetahuan seseorang dapat didapati dari pengamatan tentang suatu objek tertentu. Semakin banyak aspek positif dari objek yang diketahui, akan menimbulkan sikap positif terhadap objek tertentu (Notoadmojo, 2010).

\section{Gambaran Kualifikasi Pendidikan Petugas Rekam Medis di unit Pendaftaran RSU Madani}

Berdasarkan hasil wawancara yang dilakukan peneliti, diketahui bahwa petugas pendaftaran kurang memperhatikan dan mengetahui tentang sistem penomoran rekam medis. Menurut Asti (2005), berpendapat bahwa tingkat pendidikan akan mengubah sikap dan cara berpikir ke arah yang lebih baik dan tingkat kesadaran yang tinggi akan memberikan kesadaran lebih tinggi dalam berwarga negara serta memudahkan untuk pengembangan kepribadian. Sedangkan menurut Sedamaryanti (2011), melalui pendidikan seseorang dipersiapkan untuk memiliki bekal agar siap tahu, mengenal dan mengembangkan metode berpikir secara sistematik agar dapat memecahkan masalah yang akan dihadapi dalam kehidupan seharihari. Berdasarkan atas dua pendapat tersebut di atas, diharapkan semakin tinggi kualifikasi pendidikan petugas pendaftaran, maka semakin kecil kemungkinan duplikasi penomoran yang dilakukan oleh petugas pendaftaran.

Bedasarkan hasil observasi yang dilakukan peneliti, diketahui bahwa petugas rekam medis di unit pendaftaran 
berpendidikan SLTA/Sederajat dimana seharusnya yang bekerja di instalasi rekam medis harus berpendidikan rekam medis .

Hal ini sesuai dengan penelitian Muldiana (2016) di Rumah Sakit Atma Jaya, terjadi duplikasi nomor rekam medis sebanyak 18 sampel, dengan faktor-faktor penyebab terjadinya duplikasi nomor rekam medis dikarenakan kualifikasi pendidikan, pengetahuan dan pengalaman kurang teliti dan kurang mengetahui tentang sistem penomoran rekam medis.

\section{Gambaran Pengetahuan Petugas Rekam Medis di unit Pendaftaran RSU Madani}

Berdasarkan hasil wawancara dengan petugas pendaftaran, menunjukkan kurang mengetahui tentang sistem penomoran rekam medis. Hasil ini sesuai dengan hasil penelitian yang dilakukan oleh Winarni (2010), menyatakan jika satu diantara faktor-faktor yang memengaruhi duplikasi penomoran rekam medis pada petugas pendaftaran adalah faktor pengetahuan, karena menurut Notoatmodjo (2010), pengetahuan adalah hasil penginderaan manusia, atau hasil tahu seseorang terhadap objek melalui indera yang dimilikinya (mata, hidung, telinga dan sebagainya) sehingga dapat di simpulkan jika semakin besar tingkat pengetahuan yang dimiliki petugas maka semakin kecil peluang petugas pendaftaran untuk melakukan duplikasi penomoran rekam medis. Jadi sebaiknya petugas rekam medis perlu pelatihan dan meningkatkan wawasan yang luas.

\section{Gambaran Pengalaman Petugas Rekam Medis di unit Pendaftaran RSU Madani}

Berdasarkan hasil wawancara dengan petugas pendaftaran, menunjukkan kurang mengetahui tentang alur pendaftaran dan pentingnya dalam memberikan penomoran rekam medis. Menurut Haditono (2003), pengalaman merupakan suatu proses pembelajaran dan pertambahan perkembangan potensi bertingkah laku baik dari pendidikan formal maupun non formal atau dapat diartikan sebagai suatu proses yang membawa seseorang kepada suatu pola tingkah laku yang lebih tinggi. Suatu pembelajaran juga mencakup perubahaan yang relatif tepat dari perilaku yang diakibatkan pengalaman, pemahaman dan praktek. Suatu perusahaan akan cenderung memilih tenaga kerja yang berpengalaman dari pada yang tidak berpengalaman. Hal ini disebabkan mereka yang berpengalaman lebih berkualitas dalam melaksanakan pekerjaan sekaligus tanggung jawab yang diberikan perusahaan dapat dikerjakan sesuai dengan ketentuan atau pemintaan perusahaan. Oleh karena itu, pengalaman kerja mempunyai manfaat bagi perusahaan maupun karyawan. Sebaiknya petugas rekam medis perlu pelatihan dan meningkatkan wawasan luas.

Gambaran Standar Operasional Prosedur (SOP) Terhadap Duplikasi Penomoran Berkas Rekam Medis .

Dari hasil observasi, di RSU Madani belum tersedianya SOP tentang penomoran berkas rekam medis, hal ini dapat mengakibatkan petugas belum mengetahui langkah apa saja dan tata cara yang harus dilakukan dalam memberi nomor rekam medis .

Standar operasional prosedur dibuat berdasarkan kebijakan dari instalasi rumah sakit sendiri dengan ketetapan dari permenkes No. 269/Menkes/PER/III/2008 tentang rekam medis, yang menyatakan bahwa di setiap unit pelayanan rekam medis harus memiliki standar operasional prosedur (SOP). Sistem penomoran di unit rekam medis merupakan salah satu bagian penting dalam melakukan registrasi pasien, karena sistem penomoran merupakan salah satu identitas pasien, yang membedakan antara pasien satu dengan pasien yang lain. Maka standar operasional prosedur tentang penomoran harus ditetapkan agar terciptanya pelayanan yang baik dan sesuai dengan kaedah-kaedah atau standar yang berlaku di pengelolaan rekam medis bagian penomoran registrasi pasien dan meminimalisir terjadinya duplikasi penomoran rekam medis. 


\section{Gambaran Penggunaan KIUP Terhadap Duplikasi Penomoran Berkas Rekam Medis}

Ditemukan di RSU Madani belum tersedia Kartu Indeks Utama Pasien (KIUP). Hal ini dikarenakan standar operasional prosedur dalam pengembangan sarana dan prasarana belum ada serta kurangnya pengetahuan petugas rekam medis di RSU Madani, tentang kartu indeks utama pasien (KIUP). Menurut Robetty (2015), dalam mempermudah pencarian berkas rekam medis maka diperlukan suatu alat yang dapat membantu petugas untuk penghematan waktu dalam pencarian berkas. Alat tersebut adalah KIUP atau Kartu Indeks Utama Pasien, KIUP adalah suatu kartu katalog yang berisikan nama semua penderita yang pernah berobat ke rumah sakit. Informasi yang terkandung dalam KIUP merupakan kunci untuk menemukan berkas rekam medis pasien. Dengan tidak adanya KIUP ini maka petugas akan kesulitan dalam melayani pasien yang tidak membawa kartu berobat, dan petugas memberi nomor baru kepada pasien, oleh karena itu terjadinya duplikasi berkas rekam medis.

\section{KESIMPULAN}

Dari hasil penelitian yang telah dilakukan di RSU Madani, peneliti dapat menarik kesimpulan bahwa :

1. Petugas pendaftaran seluruhnya berpendidikan SLTA/sederajat sehingga kurang mengetahui dan pentingnya penomoran rekam medis.

2. Dari analisis 233 berkas rekam medis, diperoleh bahwa terjadi duplikasi nomor rekam medis sebanyak 32 rekam medis $(13,73 \%)$ dan yang tidak mengalami duplikasi nomor berkas rekam medis sebanyak 201 rekam medis $(86,26 \%)$.

3. Tidak terdapat Standar Operasional Prosedur (SOP) untuk penomoran dan penyimpanan berkas rekam medis

4. Tidak tersedianya KIUP, buku register pendaftaran daan tracer di instalasi rekam medis RSU Madani.

\section{SARAN}

Adapun saran yang dapat diberikan berdasarkan penelitian ini adalah sebagai berikut:

1. Diharapkan bagi petugas pendaftaran dan penyimpanan agar memiliki bank nomor dan lebih teliti dalam pemberian nomor rekam medis pasien.

2. Diharapkan pada pimpinan RSU Madani agar melakukan pelatihan kepada petugas rekam medis khususnya dibagian pendaftaran dan penyimpanan agar kinerjanya semakin baik.

3. Melakukan evaluasi terhadap fasilitas yang ada untuk dapat menunjang lagi pelaksanaan rekam medis di RSU Madani.

4. Disarankan hasil penelitian ini dapat dilanjutkan kembali untuk peneliti berikutnya yang memiliki topik permasalahan yang sama.

\section{DAFTAR PUSTAKA}

Budi, Savitri Citra. (2011). Manajemen Unit Kerja Rekam Medis. Jogjakarta: Quantum Sinergis Media.

Depkes (2006). Pedoman Penyelenggaraan Dan Prosedur Rekam Medis Rumah Sakit Di Indonesia. Jakarta : Depkes RI.

Departemen Kesehatan RI. 2006. Petunjuk teknis penyelenggaraan rekam medis/medical record rumah sakit. Jakarta : Departemen Kesehatan RI.

Departemen Kesehatan RI. (2008). Peraturan Menteri Kesehatan RI No. 269/MenKes/PER/III/2008. Jakarta : Depkes RI.

Hasibuan, S (2001). Manajemen Sumber Daya Manusia : Pendekatan Non Sekuler. Surakarta : Muhammadiyan University Press.

Hatta, Gemala., R. (2008). Pedoman Manajemen Informasi Kesehatan di Sarana Pelayanan Kesehatan. Jakarta: Universitas Indonesia.

Hatta, Gemala. (2011). Pedoman Manajemen Informasi Kesehatan di Sarana Pelayanan Kesehatan. Jakarta : Universitas Indonesia (UI-Press). 
Huffman, Edna K, RRA. (1994). Health Information Management, Tenth Edition, Berweyn, Illinois Physicians' Record Company.

Notoatmodjo. (2010). Ilmu Perilaku Kesehatan. Jakarta : Rineka Cipta.

Notoatmodjo, S. (2012). Metodologi Penelitian Kesehatan. Jakarta: Rhineka Cipta.
Rustiyanto, E.(2009). Etika profesi Perekam Medis Dan Informasi kesehatan. Yogyakarta: Graha Ilmu.

Rustianto, Ery., Rahayu, Warih Ambar. (2011). Manajemen Filing Dokumen Rekam Medis Dan Informasi Kesehatan. Jogjakarta : Politeknik Kesehatan Permata Indonesia.

Saryono. (2010). Metodologi Penelitian Kesehatan.Yogyakarta : Mitra Cendika. 